\title{
Studi Awal: Analisis Sifat Fisika Lemak Babi Hasil Ekstraksi Pada Produk Pangan Olahan
}

\author{
Preliminary Studies: Analysis Of Physical Properties Of Lard Extraction Products On \\ The Meat Processed
}

\author{
Muhammad Taufik ${ }^{1 *}$, Desi Ardilla² Dafni Mawar Tarigan², Muhammad Thamrin², \\ Mariany Razali ${ }^{3}$, Muhammad Iqbal Afritario² \\ 1Universitas Sumatera Utara \\ 2Universitas Muhammadiyah Sumatera Utara \\ 3Universitas Tjut Nyak Dien \\ *Email: muhammad.taufik@usu.ac.id
}

\begin{abstract}
ABSTRAK
Kemajuan teknologi dan beragamnya produk pangan olahan telah berkembang pesat dengan kualitas dan harga yang istimewa. Seringkali dijumpai lemak babi bercampur dengan produk olahan makanan lain. Hal ini menyebabkan banyak ahli untuk menemukan metode pemeriksaan sifat fisika dari lemak babi secara sederhana dan murah. Penelitian ini merupakan kajian awal dalam analisis sifat fisika lemak babi yang bertujuan untuk menganalisis sifat fisika Lemak Babi hasil ekstraksi pada Produk Pangan Olahan. Pada penelitian ini, variasi konsentrasi n-heksan dan berat sampel: 20\%: 10 g, 30\%: 20 g, 40\%: 30 g, 50\% : 40 g. Berat jenis diperoleh berturut turut : 0,8208, 0,8210, 0,8215, 0,8215. Indeks bias diperoleh berturut turut: 1,502, 1,502, 1,503, 1,505. Titik leleh diperoleh 42,638, 42,700, 42,700, 42,700. Bilangan iodium diperoleh: 46,441, 46,449, 46,460, 46,463. Bilangan penyabunan diperoleh: 228,446, 228,440, 228,435, 228,428.
\end{abstract}

Kata Kunci: Analisis, Ekstraksi, Lemak babi, Sifat fisika

\begin{abstract}
Technological advances and diversity of the meat processed have grown tremendously with exceptional quality and price. Often found pork fat mixed with other meat processed. This led many experts to find a simple and inexpensive method of examining the physical properties of pig fat. This research is a preliminary study in the analysis of fat physics properties of pigs that aims to analyze the physical properties of extraction Pigs on the meat processed. In this study, n-hexane was carried used variated of concentrations and sample weights respectively : 20\%: $10 \mathrm{~g}, 30 \%: 20 \mathrm{~g}, 40 \%: 30 \mathrm{~g}, 50 \%$ : $40 \mathrm{~g}$. Specific gravity is obtained respectively $0.8208,0.8210,0.8215,0.8215$. The refractive index was obtained respectively $1.502,1.502,1.503,1.505$. The melting point was obtained respectively 42,638 , $42,700,42,700,42,700$. Iodine numbers were obtained respectively 46,441, 46,449, 46,460, 46,463 and the saponification numbers were obtained respectively $228,446,228,440,228,435,228,428$.
\end{abstract}

Keywords: Analysis, Extraction, Lard, Physical properties 


\section{A. PENDAHULUAN}

Pangan merupakan kebutuhan yang paling mendasar bagi manusia, sehingga ketersediaan pangan perlu mendapat perhatian yang serius baik kuantitas maupun kualitasnya (Gustiani, 2009). Indonesia merupakan negara dengan mayoritas penduduk muslim sebanyak 207,2 juta jiwa dengan presentasi sebesar $85 \%$ dari total penduduk 237 juta jiwa. Dalam ajaran agama Islam terdapat makanan halal dan makanan haram begitu juga dengan minuman. Selain faktor keamanan pangan, faktor kehalalan suatu produk pangan juga harus menjadi perhatian masyarakat muslim (Citrasari, 2013).

Lemak babi merupakan bahan dasar makanan yang biasa digunakan sebagai minyak goreng atau sebagai pelengkap masakan seperti layaknya lemak sapi atau kambing, atau sebagai mentega. Kualitas rasa dan kegunaan dari lemak babi sendiri bergantung pada bagian apa lemak tersebut diambil dan bagaimana lemak tersebut diproses. Lemak babi memiliki kandungan lemak jenuh dan kolesterol yang lebih rendah daripada mentega. Lemak pada babi perlu melalui proses pengolahan untuk dapat menjadi lemak babi yang dapat menjadi bahan makanan. Lemak babi mengandung $3770 \mathrm{~kJ}$ energi per 100 gram. Titik didihnya antara 86-113 ${ }^{\circ} \mathrm{C}$ tergantung pada letak lemak tersebut pada tubuh babi. Titik asapnya $121-218{ }^{\circ} \mathrm{C}$. Nilai iodinnya 71,97. Memiliki pH sekitar 3.4, nilai saponifikasi 255,90, titik lelehnya 36,8 dan bobot jenisnya 0,812 (Hilda, 2014).

Seiring dengan kemajuan teknologi, terdapat berbagai produk pangan yang sangat beragam, dengan kualitas dan harga yang istimewa. Hanya saja, terkadang untuk mendapatkannya, diperlukan bahan-bahan yang diperoleh dari salah satu atau beberapa bagian dari tubuh babi dan kemudian mencampur bagian tersebut dengan produk olahan makanan lain. Secara ekonomis, penggunaan bahan babi mampu memberikan banyak keuntungan, karena murah dan mudah didapat. Bahan-bahan tersebut ketika sudah diolah menjadi produk pangan menjadi sangat sulit untuk dikenali (BPOM RI, 2007).

Kasus makanan mengandung bahan dari babi marak terjadi di Indonesia sejak tahun 1980-an sampai sekarang (Fibriana, 2010). Oleh karena itu, pengetahuan terhadap berbagai kemungkinan penggunaan unsur babi perlu terus ditingkatkan (BPOM RI, 2007). Salah satu contoh kasus terindikasi mengandung babi adalah mengenai kasus minyak babi pada restoran Solaria yang muncul pada 15 agustus 2013 sehingga PT. Sinar Solaria mengalami fase kritis (Armandhanu, 2013). PT. Sinar Solaria menbawahi restoran Solarian saar itu sedang dilanda krisis akibat restoran tersebut belum memiliki sertifikasi hahal dari MUI dan restoran Solaria juga dilanda isu minyak babi yang digunakan dalam racikan bumbu masakannya, selain itu ada PT. Walls Indonesia terutama pada produk es krim Magnum yang diisukan terdapat minyak babi di dalam kemasan dari es krimnya (Fandy, 2011), dan baru-baru ini kasus yang menghebohkan di Indonesia adalah beredarnya empat produk mie instan asal Korea positif mengandung fragmen DNA spesifik babi. Keempat produk mengandung babi itu yakni Samyang dengan nama produk U-Dong, Nongshim dengan naman produk Shin Ramyun Black, Samnyang dengan produk mie Instan rasa kimchi, dan Ottogi dengan nama produk Yeul Ramen (BBC, 2017).

Koirewoa (2012), telah melaporkan bahwa ekstraksi dengan cara maserasi sangat menguntungkan dalam isolasi senyawa bahan alam karena selain murah dan mudah dilakukan. Pemilihan pelarut untuk proses maserasi akan memberikan efektivitas yang tinggi dengan memperhatikan kelarutan senyawa bahan alam dalam pelarut tersebut. Dalam hal ini pelarut yang digunakan ialah nHeksana yang merupakan pelarut non polar yang dimana ditujukan secara khusus untuk ekstraksi minyak atau penggunaan pada laboratorium.

Hermanto (2008), menyatakan Terdapat Perbedaan Komposisi Asam Lemak Yang Cukup Signifikan Diantara Ketiga Sampel Lemak Hewani Berdasarkan Hasil analisa GCMS dimana kandungan asam lemak jenuh (SFA) pada lemak sapi jauh (68\%) dibandingkan dengan lemak ayam (33\%) dan lemak babi (21\%), sedangkan kandungan asam lemak jenuh ganda (PUFA) pada lemak babi relative lebih besar (25\%) dari pada lemak ayam (18\%) dan lemak sapi (1.2\%).

Beberapa metode yang telah digunakan untuk identifikasi daging babi atau lemak babi dalam makanan antara lain UPLC dengan marker Myoglobin, Polymerase Chain Reaction dan Nanobiophrobe (Mubayinah, 2016). Kelemahan metode-metode tersebut 
memerlukan banyak tenaga dan waktu sehingga diperlukan tehnik analisis yang cepat dan mudah.

Sifat fisika lemak babi dapat dilaksanakan dengan cara sederhana namun mudah diterapkan sebagai penelitian awal dalam mempelajari sifat fisika dari lemak babi yang terkandung dalam produk olahan. Sifat Fisika yang diamati meliputi : berat jenis, indeks bias, titik leleh, bilangan iodium, dan bilangan penyabunan. Tujuan penelitian ini adalah untuk menganalisis sifat fisika Lemak Babi hasil ekstraksi pada Produk Pangan Olahan.

\section{B. METODOLOGI \\ Bahan dan Alat}

Bahan yang digunakan adalah larutan produk pangan olahan (corned babi). Bahan kimia yang digunakan dalam penelitian ini adalah $\mathrm{KOH} / \mathrm{NaOH}, \mathrm{HCL}, \mathrm{Na}_{2} \mathrm{~S}_{2} \mathrm{O}_{3}$, indikator pp, dietil eter, n-heksana, iodium-Bromida, aquades, indikator Kanji, $\mathrm{CH}_{3} \mathrm{COOH}, \mathrm{CHCL}_{3}$, larutan jenuh $\mathrm{KI}$, kloroform, dan $\mathrm{H}_{2} \mathrm{SO}_{4} 0,5 \%$.

Alat yang digunakan adalah seperangkat alat spektroskopi UV-Vis merk Genesis, erlenmeyer, beker glass, biuret, corong pisah, pipet tetes, pipet ukur, labu takar $500 \mathrm{~mL}$, beaker glass, kaca arloji, neraca analitik, pisau, sarung tangan, tabung reaksi, penjepit, desikator, hot plate, oven, kertas saring Whatman.

\section{Pelaksanaan Penelitian \\ Preparasi dan Ekstraksi}

Sampel lemak babi yang diuji diambil dari sampel corned babi Pasar Tradisional yang ada di Kota Medan selanjutnya dilakukan persiapan untuk ekstraksi sampel. Sampel ditimbang, dihaluskan, diekstraksi dengan cara maserasi selama 2 jam dengan pelarut n-Heksana, disaring lemak yang sudah meleleh dengan kain flannel, disentrifugasi pada $3000 \mathrm{rpm}$ selama 20 menit, disaring dengan kertas Whatman yang ditaruh $\mathrm{Na}_{2} \mathrm{SO}_{4}$ anhidrat, dikeringkan, diulangi untuk setiap perlakuan.

\section{Analisis Sifat Fisika Lemak Babi hasil ekstraksi}

Analisis sifat fisika dilakukan meliputi uji: Berat Jenis, Indeks bias, Titik Leleh, Bilangan Iodium dan Bilangan Penyabunan.

\section{Berat Jenis}

Lemak babi dimasukkan ke dalam dengan piknometer $25 \mathrm{ml}$ sampai tanda garis. Piknometer didinginkan pada suhu $25^{\circ} \mathrm{C}$ selama 15 menit kemudian ditimbang. Sebagai pembanding dihitung berat piknometer kosong dan berat aquades pada suhu $25^{\circ} \mathrm{C}$, berat kosong piknometer (W1), berat piknometer + lemak babi (W3), berat piknometer + aquadest (W2). Penghitungan berat jenis dengan menggunakan rumus :

Ket :

$$
\rho(\text { rho })=\frac{W 3-W 1}{W 2-W 1}
$$

$$
\begin{aligned}
& \rho(\text { rho })=\text { Berat jenis } \\
& \mathrm{W} 1=\text { berat kosong piknometer } \\
& \mathrm{W} 2=\text { berat piknometer }+ \text { aquadest } \\
& \mathrm{W} 3=\text { berat piknometer }+ \text { lemak babi }
\end{aligned}
$$

\section{Indeks Bias}

Sampel yang akan diperiksa indeks biasnya diteteskan pada tempat sampel refraktometer. Kemudian ditutup dengan rapat dan dibiarkan cahaya melewati larutan dan melalui prisma agar cahaya pada layar dalam alat tersebut terbagi menjadi dua. Digeser tanda batas tersebut dengan memutar knop pengatur, sehingga memotong titik perpotongan dua garis diagonal yang saling berpotongan terlihat pada layar. Mengamati dan membaca skala indeks bias yang ditunjukan oleh jarum layar skala melalui mikroskop. Untuk menentukan indeks bias dapat dihitung menggunakan rumus berikut: $\quad \mathrm{N}=\mathrm{c} / \mathrm{v}$

Keterangan: $\mathrm{n}=$ indeks bias

$$
\begin{aligned}
& \mathrm{c}=\text { kecepatan cahaya diudara } \\
& \mathrm{v}=\text { kecepatan cahaya dalam zat }
\end{aligned}
$$

\section{Titik Leleh}

Sampel dimasukkan kedalam capillary glass tubing $1 \mathrm{~cm}$. Ditempatkan di dalam beaker glass berisi es batu. Dimasukkan kedalam refrigator pada suhu $4^{\circ} \mathrm{C}-10^{\circ} \mathrm{C}$ selama 16 jam. Diikatkan capillary glass tubing pada termometer. Dimasukkan thermometer tersebut $\mathrm{di}$ atas kedalam beaker glass berukuran $600 \mathrm{~mL}$ berisi air destilasi sekitar $300 \mathrm{~mL}$. Diatur suhu air dalam beaker glass pada suhu $8-10^{\circ} \mathrm{C}$ dibawah. melting point contoh dan suhu air dipanaskan perlahan dengan. pengadukan magnetic stirrer. Dilanjutkan pemanasan dan suhu diamati dari saat sampel meleleh sampai sampel naik pada batas atas. 


\section{Bilangan Iodium}

Ditimbang sebanyak 5 gr Lemak masukkan ke dalam erlenmeyer. Ditambahkan $10 \mathrm{ml}$ kloroform ditambahkan $25 \mathrm{ml}$ pereaksi iodiumBromida dan disimpan ditempat gelap selama 30 menit. Kemudian tambahkan 10 ml larutan KI $15 \%$. Dan ditambahkan $50 \mathrm{ml}$ dan aquadest yang telah didihkan. Dan dititrasi dengan $\mathrm{Na} 2 \mathrm{~S} 2 \mathrm{O} 3$ dan ditambahkan ind. Kanji. ml titrasi ditandai dengan warna biru tepat hilang. Bilangan iodium $=$

$$
\frac{(\mathrm{V} \text { tio blangko }-\mathrm{V} \text { tio sampel })-\mathrm{N} \text { tio } \times 12,6}{\text { berat sampel }}
$$

\section{Bilangan Penyabunan}

Sampel minyak ditimbang seberat kurang lebih 5 gram dalam erlenmeyer. Kemudian ditambahkan sebanyak $50 \mathrm{ml} \mathrm{KOH} 0,5 \mathrm{~N}$ alkoholik. Sesudah ditutup dengan pendinginselanjutnya didihkan sampai minyak tersabunkan secara sempurna ditandaidengan tidak telihat butir-butir lemak atau minyak dalam larutan. Setelah didinginkan kemudian dititrasi dengan $\mathrm{HCl} \quad 0,5 \mathrm{~N}$ menggunakan indikator PP. Tititk akhir titrasi ditandai dengan tepat hilangnya warna merah. Perhitungan bilangan penyabunan dapat dihitung menggunakan rumus sebagai berikut :

Bilangan penyabunan $=$

$\frac{(\text { b-a)ml x N HCL x } 56}{\text { gram sampel }} \times 100 \%$

$\mathrm{a}=$ volume $\mathrm{HCL}$

$\mathrm{b}=$ volume $\mathrm{KOH}$

$\mathrm{N}=$ normalitas HCL 0,016

\section{HASIL DAN PEMBAHASAN Preparasi dan ekstraksi}

Proses preparasi dan ekstraksi dilakukan dengan menimbang sampel corned babi pada variasi: $10 \mathrm{~g}, 20 \mathrm{~g}, 30 \mathrm{~g}$, dan $40 \mathrm{~g}$. Metode maserasi dikembangkan selama 2 jam dengan menggunakan pelarut $n$-Heksan dengan variasi konsentrasi 20\%, 30\%, 40\%, dan 50\%. Proses sentrifugasi dilakukan pada $3000 \mathrm{rpm}$ selama 20 menit, disaring dengan kertas Whatman yang ditaruh $\mathrm{Na}_{2} \mathrm{SO}_{4}$ anhidrat untuk mengikat molekul air pada senyawa yang dihasilkan.

\section{Analiss Sifat Fisika lemak babi hasil ekstraksi}

Berdasarkan data rata-rata hasil pengamatan pengaruh $\mathrm{n}$-Heksan dan berat sampel terhadap masing-masing parameter dapat dilihat pada Tabel 1 berikut ini:

Tabel 1 Hasil Pengamatan Sifat Fisika lemak babi hasil ekstraksi

\begin{tabular}{cccccccc}
$\begin{array}{c}\text { Konsen- } \\
\text { trasi } \\
\text { n-Heksa } \\
\text { na (\%) }\end{array}$ & $\begin{array}{c}\text { Berat } \\
\text { Sampel } \\
\text { (g) }\end{array}$ & $\begin{array}{c}\text { Berat } \\
\text { Jenis }\end{array}$ & $\begin{array}{c}\text { Indeks } \\
\text { Bias }\end{array}$ & $\begin{array}{c}\text { Titik } \\
\text { leleh }\end{array}$ & $\begin{array}{c}\text { Bil. } \\
\text { Iodium }\end{array}$ & $\begin{array}{c}\text { Bil. } \\
\text { Penya- } \\
\text { bunan }\end{array}$ \\
\hline $\mathrm{K} 1=20 \%$ & B1=10 & 0.8208 & 1.502 & 42.638 & 46.441 & 228.446 \\
K2=30\% B2=20 & 0.8210 & 1.502 & 42.700 & 46.449 & 228.440 \\
K3 $=40 \%$ & B3=30 & 0.8215 & 1.503 & 42.700 & 46.460 & 228.435 \\
K4=50\% B4=40 & 0.8215 & 1.505 & 42.700 & 46.463 & 228.428 \\
\hline
\end{tabular}

\section{Berat Jenis}

Berat jenis merupakan perbandingan relatif antara massa jenis sebuah zat dengan massa jenis air murni. Data berat jenis lemak babi yang diperoleh adalah seperti pada Gambar 1 di bawah ini:

\section{Berat Jenis}

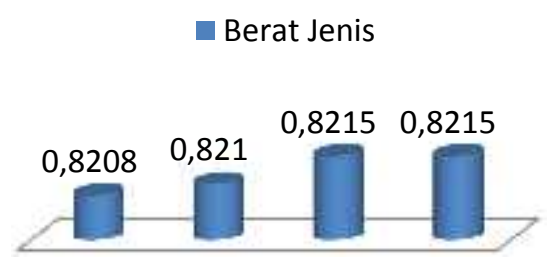

$\mathrm{K} 1, \mathrm{~B} 1 \mathrm{~K} 2, \mathrm{~B} 2 \quad \mathrm{~K} 3, \mathrm{~B} 3 \quad \mathrm{~K} 4, \mathrm{~B} 4$

Gambar 1 Data berat jenis lemak babi hasil ekstraksi

Berdasarkan Gambar 1 dapat dilihat bahwa semakin tinggi konsentrasi n-Heksana dan berat sampel maka berat jenis akan semakin meningkat. Berdasarkan data Badan Pusat Statistik (2005), spesifikasi lemak babi adalah kisaran antara 0,917-0,938 g/ml. Hasil penelitian Hilda (2014), menunjukkan berat jenis lemak babi terhadap produk pangan bakso di padangsidimpuan yaitu sebesar $0,812 \mathrm{~g} / \mathrm{ml}$. Jika dibandingkan dengan hasil tersebut maka nilai berat jenis dari hasil penelitian ini tidak jauh berbeda. Bobot jenis dapat menunjukkan komponen yang terkandung di dalam bahan serta dapat pula menunjukkan kemurnian minyak.

\section{Indeks Bias}

Indeks bias suatu zat merupakan perbandingan kelajuan cahaya di udara dengan kelajuan cahaya di dalam zat tersebut. Data indeks bias lemak babi hasil ekstraksi dapat dilihat pada Gambar 2 berikut ini: 


\section{Indeks Bias}

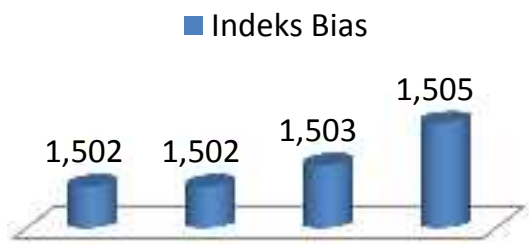

K1, B1 K2, B2 K3, B3 K4, B4

Gambar 2 Data indeks bias lemak babi hasil ekstraksi

Berdasarkan Gambar 2 dapat dilihat bahwa semakin tinggi konsentrasi n-Heksana dan berat sampel maka terdapat peningkatan indeks bias. Pada penelitian ini, indeks bias yang diperoleh lebih tinggi dibandingkan data penelitian sebelumnya yakni Hilda (2014), yaitu 1,498 ${ }^{\circ}$ Brix. Pada perlakuan ini nilai indeks bias dengan nilai tertinggi terdapat pada perlakuan konsentrasi n-Heksana $50 \%$ yaitu 1,505 ${ }^{\circ}$ Brix. Hal ini disebabkan oleh komponen bergugus oksigen dalam minyak atsiri yang terekstrak oleh metanol tersuling lebih banyak sehingga kerapatan minyak akan bertambah dan cahaya yang datang akan sulit dibiaskan menyebabkan nilai indek biasnya menjadi lebih besar.

\section{Titik Leleh}

Titik leleh merupakan temperatur dimana zat padat berubah menjadi cairan pada tekanannya satu atmosfer. Data titik leleh lemak babi hasil ekstraksi dapat dilihat pada Gambar 3 berikut ini :

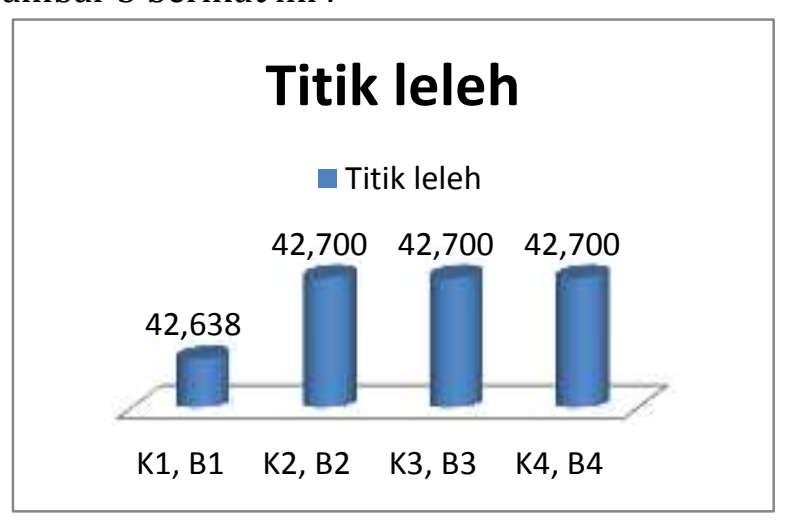

Gambar 3 Data titik leleh lemak babi hasil ekstraksi

Berdasarkan Gambar 3 dapat dilihat bahwa rata - rata titik leleh lemak babi yang dianalisis memiliki nilai yang hampir sama. Hasil penelitian menunjukkan bahwa titik leleh tertinggi terdapat pada perlakuan konsentrasi n-Heksana 30 sampai $50 \%$ yaitu $42,70{ }^{\circ} \mathrm{C}$.

\section{Bilangan Iodium}

Bilangan iodium menyatakan ukuran ketidakjenuhan minyak atau lemak dan berkaitan dengan kandungan asam lemak tidak jenuh dalam minyak atau lemak. Data bilangan iodium lemak babi hasil ekstraksi dapat dilihat pada Gambar 4 berikut ini :

\section{Bilangan lodium}

$$
\text { - Bilangan lodium }
$$

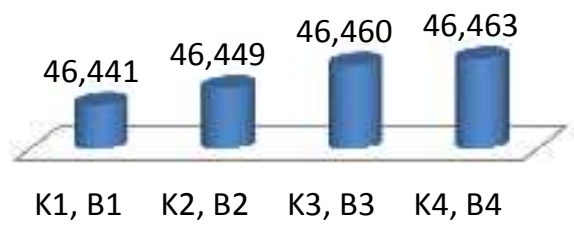

Gambar 4 Data bilangan iodium lemak babi hasil ekstraksi

Berdasarkan Gambar 4 dapat dilihat bahwa bilangan iodium rata rata dari 46,441 sampai 46,463. Hasil pennelitian Hilda (2014), mengemukakan bilangan iodium lemak sapi pada sampel bakso berkisar 71,97, sedangkan Hermanto (2013), mengemukakan bilangan iodium pada lemak sapi berkisar 72,69. Adapun faktor-faktor yang mempengaruhi bilangan iodium dalam suatu minyak lemak adalah 1). Lamanya pemanasan, 2). Suhu, 3). Kecepatan aerasi.

\section{Bilangan Penyabunan}

Bilangan penyabunan adalah jumlah miligram $\mathrm{KOH}$ yang di perlukan untuk menyabunkan satu gram lemak atau minyak. Data bilangan penyabunan lemak babi hasil ekstraksi dapat dilihat pada Gambar 5 berikut ini :

\section{Bil. Penyabunan}

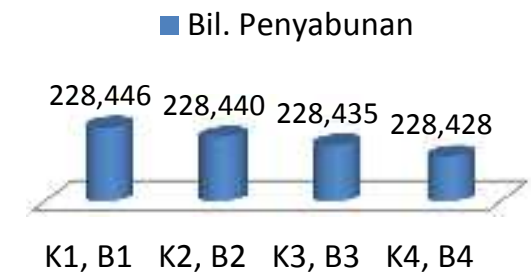

Gambar 5 Data Bilangan Penyabunan lemak babi hasil ekstraksi 
Berdasarkan Gambar 5 dapat dilihat bahwa bilangan penyabunan lemak babi berkisar dari 228,428 sampai 228,446 . Bilangan penyabunan dipengaruhi oleh berat molekul. Semakin tinggi berat molekul maka bilangan penyabunan akan semakin rendah. Semakin rendah bilangan penyabunan maka kualitas minyak akan semakin baik. Bilangan penyabunan dapat dipergunakan untuk menentukan berat molekul minyak dan lemak secara kasar. Angka penyabunan yang besar maka minyak tersebut tersusun oleh asam-asam lemak dengan rantai yang pendek.

\section{KESIMPULAN}

Berdasarkan penelitian yang telah dilakukan dapat diambil beberapa kesimpulan sebagai berikut:

1. Sifat fisika Lemak Babi hasil ekstraksi pada Produk Pangan Olahan telah dianalisis meliputi meliputi berat jenis, indeks bias, titik leleh, bilangan iodium, dan bilangan penyabunan.

2. Variasi konsentrasi n-heksan dan berat sampel: $20 \%$ : $10 \mathrm{~g}, 30 \%$ : $20 \mathrm{~g}, 40 \%: 30 \mathrm{~g}$, $50 \%: 40$ g. Berat jenis diperoleh berturut turut: $0,8208,0,8210,0,8215,0,8215$. Indeks bias diperoleh berturut turut: 1,502, 1,502, 1,503, 1,505. Titik leleh diperoleh berturut turut 42,638, 42,700, 42,700, 42,700. Bilangan iodium diperoleh berturut turut: 46,441, 46,449, 46,460, 46,463. Bilangan penyabunan diperoleh berturut turut : 228,446, 228,440, 228,435, 228,428.

\section{SARAN}

Disarankan untuk menganalisis sifat mikrobiologi serta interaksi fisika dan kimia lemak babi hasil ekstraksi menggunakan metode instrumentasi sehingga akan diperoleh model analisis yang akurat dan mudah dilaksanakan.

\section{DAFTAR PUSTAKA}

Armandhanu, Denny dan Z Darmawan. 2013. Bagaimana Isu Minyak Babi Menghantam Restoran Solaria. http://nasional.news. viva.co.id/news/ read/436708bagamana-isu-minyak-babi-menghantamrestoran-solaria. Diakses pada tanggal 01 Oktober 2017.
BBC, 2017. Kasus Mie Tercemar Babi. http://www.bbc.com/indonesia/majalah40318156. Diakses pada tanggal 01 Oktober 2017.

Burlian, Paisol, 2014. Reformulasi Yuridis Pengaturan Produk Pangan Halal Bagi Konsumen Muslim Di Indonesia. [Skripsi] IAIN. Palembang.

BPOM RI. 2007. Keamanan Pangan. Badan Pengawas Obat dan Makanan. 11/IV.

Citrasari, Dewi. 2015. Penentuan Adulterasi Daging Babi Pada Pada Nugget Ayam Menggunakan NIR dan Kemometrik. [Skripsi]. Fakultasi Farmasi. Universitas Jember.

Doni, N Danar. 2017. Makanan Haram yang Pernah Aku Lumat. http:// www.kompasiana.com/erikrun/makanan -haram-yang-pernah-akulumut_5500707c81311275efa79cb. Diakses Pada Tanggal 01 Oktober 2017.

Fandi, 2011. MUI Tidak Benar Es Krim Magnum Mengandung Enzim Babi. http:// www.kompasiana.com/afsee/mui-tidakbenar-es-krim-mengandung-enzimbabi_5500a3c2a33311e77251180b. Diakses Pada Tanggal 01 Oktober 2017.

Fibriana, F., Widianti, T. \& Retnoningsih, A. 2010. Deteksi Kandungan Daging Babi Pada Bakso Yang Dijajankan Dipusat Kota Salatiga Menggunakan Teknik Polimerase Chain Reaction. Biosaintifi, 2(1): 10-17.

Gustiani, E. 2009. Pengendalian Cemaran Mikroba Pada Bahan Pangan Asal Ternak (Daging dan Susu) Mulai Dari Peternakan Sampai Dihidangkan. Jurnal Litbang Pertanian, 28 (3): 96-100.

Hermanto, Sandra, Anna Muawanah, Rizkina Harahap. 2008. Profil dan Karakteristik Lemak Hewani (ayam, sapi, babi) Hasil Analisa FTIR dan GCMS. Program Studi Kimia, Fakultas Sains dan Teknologi Universitas Islam Negeri Syarif Hidayatullah Jakarta: 102-109.

Koirewoa, Y.A., Fatimawali, dan Weny I.W. 2012. Isolasi dan Identifikasi Senyawa Flavonoid 
Dalam Daun Beluntas (Pluchea indica L.). J. Pharmacon 1 (1): 47- 52.

Mubayinah, A., Kuswandi, B., Wulandari, L. 2016. Penentuan Aulterasi Daging Babi Pada Sampel Burger Sapi Menggunakan Metode NIR dan Kemometrik. e-Jurnal Pustaka Kesehatan, vol. 6, pp. 1371,2012.

Razali, M. 2017. Pengaruh Konsentrasi Dan Waktu Maserasi Terhadap Total Mikroba Pada Ekstraksi Belimbing Wuluh Sebagai Pengawet Ikan Kembung. Jurnal Sains, Teknologi, Farmasi dan Kesehatan. Stikes Nurliana. Medan.

Rani Handayani, S Rukminita, I Gumilar. 2015. Karakteristik Fisiko Kimia Minyak Biji Bintaro (Cerbera Manghas) dan Potensinya sebagai Bahan Baku Pembuatan Biodiesel. [Skripsi]. Fakultas Perikanan dan Kelautan, Universitas Padjajaran.

Rompis, J.E.G dan Komansilan, 2014. Efektifitas Cara Pemasakan Terhadap Karakteristik Fisik Makanan Daging Babi Hutan. Jurnal Zooteck, VOl 34 No 2:65-70.

Srigede, G.L. 2015. Studi Identifikasi Bakteri (Salmonella Sp) Pada Jajanan Cilok Yang Dijual Di Lingkungan Sd Kelurahan Kekalik Kecamatan Sekarbela Kota Mataram. Media Bina Ilmiah. 9(7): 28-32.

Werdiningsih, W., S. Widyastuti, Nazaruddin, dan H.B. Rien. 2014. Kajian penggunaan asap cair terhadap mutu ayam bakar Taliwang. Jurnal Ilmiah Rekayasa Pertanian dan Biosistem. 2(1): 29-35.

Zita Letviany Sarungallo, Purwiyatno Hariyadi, Nuri Andarwulan, Eko Hari Purnomo. 2014. Pengaruh Metode Ekstraksi Terhadap Mutu Kimia Dan Komposisi Asam Lemak Minyak Buah Merah (Pandanus Conoideus). Jurnal Teknologi Industri Pangan. 